\title{
Genetic structure and diversity of a collection of Brassica rapa subsp. rapa L. revealed by simple sequence repeat markers
}

\author{
P. SOENGAS*, M. E. CARTEA, M. FRANCISCO, M. LEMA AND P. VELASCO \\ Misión Biológica de Galicia (CSIC), PO Box 28, E-36080·Pontevedra, Spain
}

(Revised MS received 7 December 2010; Accepted 13 December 2010; First published online 24 February 2011)

\begin{abstract}
SUMMARY
Brassica rapa subsp. rapa L. includes three different crops: turnips (roots), turnip greens (leaves) and turnip tops (inflorescences). A collection of B. rapa subsp. rapa from north-western Spain is currently kept at 'Misión Biológica de Galicia' (a research centre of the Consejo Superior de Investigaciones Científicas (CSIC), Spain). This collection has been characterized based on morphological and agronomical traits. A better understanding of the genetic diversity present in the collection is necessary in order to optimize its use and maintenance. The objectives of the present work were to assess the genetic diversity present in the B. rapa subsp. rapa collection, to establish genetic relationships among populations and to study the genetic structure of the collection. Eighty populations were analysed based on 18 simple sequence repeats (SSRs). Populations showed a broad range of genetic diversity, thus offering good potential for further genetic improvement. Most of the variability was found within the population level, probably due to high rates of allogamy, to migration and/or interchange of seed among local growers. Populations showed a low level of differentiation, grouping in just one cluster, and therefore they can be considered as samples of a highly variable metapopulation that can be used for $B$. rapa breeding programmes.
\end{abstract}

\section{INTRODUCTION}

Brassica rapa $\mathrm{L}$. is an obligate out-crossing crucifer grown worldwide as a vegetable and for edible and industrial oil, providing a large proportion of the daily food intake in many regions of the world (Ofori et al. 2008). There is a large variation in the plant organs that are consumed, which has resulted in the selection of different morphotypes depending on local preferences (Zhao et al. 2005). These crops are grown for their leaves (turnip leaves, Chinese cabbage, pak-choi, Narinosa, Komatsuna, Mizuna and Mibuna), seeds (turnip rape, Chinese turnip rape and Sarson types), inflorescences (Broccoletto, Caixin, turnip inflorescences and Zicaitai) and enlarged roots (turnips).

B. rapa is classified into different subspecies. B. rapa subsp. rapa L. includes plants used as three different crop types: turnips, turnip leaves and turnip inflorescences. It is believed that B. rapa subsp. rapa was first used for its nutritious root in Europe, which

* To whom all correspondence should be addressed. Email: psoengas@mbg.cesga.es occurred around 2500-2000 BCE (Gómez-Campo \& Prakash 1999). The spread of vegetable crops within this subspecies, such as turnip inflorescences and turnip leaves, occurred later, independently from the origin of other leafy forms in Asia (Gómez-Campo \& Prakash 1999). The long history and extensive use of cultivation of Brassica species in Galicia (north-western Spain) has given rise to a great number of landraces. They have been under cultivation for a very long time since they were among the first vegetables to be introduced into the Western Iberian Peninsula (Gómez-Campo \& Prakash 1999).

B. rapa subsp. rapa $\mathrm{L}$. is grown during the winter in the north-west of Spain, where turnip leaves and turnip inflorescences are used for human consumption in soups and stews, and turnips are mostly used for fodder. Agriculture in north-western Spain is traditional and even today growers continue to cultivate landraces in vegetable gardens for their own consumption. Commercial varieties of turnips, turnip leaves and turnip inflorescences have been selected by their use. Varieties employed as turnips have thickened roots, and they do not produce much leaf 
Table 1. List of Brassica rapa populations used in this study, including geographical origin, number of alleles and expected heterozygosity

\begin{tabular}{|c|c|c|c|c|}
\hline Accession name & $\begin{array}{l}\text { Geographical origin } \\
\text { (Galicia province) }\end{array}$ & Location & $\begin{array}{l}\text { Number of } \\
\text { alleles }\end{array}$ & $\begin{array}{c}\text { Expected } \\
\text { heterozygosity }\end{array}$ \\
\hline MBG-BRS0026 & Pontevedra & Paramos, Tui & 44 & $0 \cdot 494$ \\
\hline MBG-BRS0036 & Pontevedra & Redondela & 42 & $0 \cdot 387$ \\
\hline MBG-BRS0050 & Pontevedra & Mogor, Marín & 48 & $0 \cdot 470$ \\
\hline MBG-BRS0066 & Pontevedra & Barro & 44 & $0 \cdot 389$ \\
\hline MBG-BRS0069 & Pontevedra & Barro & 45 & $0 \cdot 438$ \\
\hline MBG-BRS0075 & Pontevedra & Lourido, Poio & 50 & $0 \cdot 442$ \\
\hline MBG-BRS0081 & Pontevedra & Forcarey & 45 & $0 \cdot 382$ \\
\hline MBG-BRS0082 & Pontevedra & Forcarey & 41 & $0 \cdot 369$ \\
\hline MBG-BRS0089 & Pontevedra & Carballida, Salceda de Caselas & 42 & $0 \cdot 327$ \\
\hline MBG-BRS0099 & A Coruña & Trazo, Ordes & 35 & $0 \cdot 289$ \\
\hline MBG-BRS0101 & Pontevedra & Cuntis & 46 & $0 \cdot 369$ \\
\hline MBG-BRS0102 & Pontevedra & La Estrada & 54 & $0 \cdot 482$ \\
\hline MBG-BRS0116 & Pontevedra & Vila de Cruces & 48 & $0 \cdot 411$ \\
\hline MBG-BRS0123 & Pontevedra & Lalín & 33 & $0 \cdot 265$ \\
\hline MBG-BRS0124 & Pontevedra & Lalín & 42 & $0 \cdot 424$ \\
\hline MBG-BRS0125 & Pontevedra & Lalín & 51 & $0 \cdot 496$ \\
\hline MBG-BRS0132 & Pontevedra & Salcedo, Pontevedra & 48 & $0 \cdot 410$ \\
\hline MBG-BRS0139 & A Coruña & Trobe, Vedra & 55 & $0 \cdot 527$ \\
\hline MBG-BRS0140 & A Coruña & Lama, Boqueixón & 54 & $0 \cdot 519$ \\
\hline MBG-BRS0143 & A Coruña & Lama, Boqueixón & 50 & $0 \cdot 489$ \\
\hline MBG-BRS0154 & A Coruña & Ordes & 48 & $0 \cdot 476$ \\
\hline MBG-BRS0155 & Ourense & Pereiro de Aguiar & 54 & $0 \cdot 495$ \\
\hline MBG-BRS0159 & Ourense & Lamas, Leiro & 48 & $0 \cdot 447$ \\
\hline MBG-BRS0163 & Ourense & Barcia, Melón & 44 & $0 \cdot 416$ \\
\hline MBG-BRS0171 & Ourense & San Cristóbal, Ribadavia & 47 & $0 \cdot 462$ \\
\hline MBG-BRS0173 & Ourense & Valongo, Cortegada & 55 & $0 \cdot 512$ \\
\hline MBG-BRS0175 & Ourense & Crespos, Padrenda & 53 & $0 \cdot 499$ \\
\hline MBG-BRS0179 & A Coruña & Betanzos & 53 & $0 \cdot 473$ \\
\hline MBG-BRS0180 & A Coruña & Betanzos & 51 & $0 \cdot 474$ \\
\hline MBG-BRS0181 & A Coruña & Betanzos & 48 & $0 \cdot 472$ \\
\hline MBG-BRS0183 & A Coruña & Carballo & 52 & $0 \cdot 500$ \\
\hline MBG-BRS0184 & A Coruña & Carballo & 54 & $0 \cdot 470$ \\
\hline MBG-BRS0186 & Ourense & A Xironda, Cualedro & 54 & $0 \cdot 523$ \\
\hline MBG-BRS0188 & Ourense & Soutoverde, A Bola & 47 & $0 \cdot 527$ \\
\hline MBG-BRS0191 & Ourense & Alonga, Toén & 49 & $0 \cdot 496$ \\
\hline MBG-BRS0193 & Ourense & Castrelo de Miño & 48 & $0 \cdot 525$ \\
\hline MBG-BRS0194 & Ourense & Barral, Castrelo de Miño & 48 & $0 \cdot 493$ \\
\hline MBG-BRS0195 & Ourense & Cartelle & 47 & $0 \cdot 489$ \\
\hline MBG-BRS0202 & Ourense & Meás, Lobeira & 45 & $0 \cdot 446$ \\
\hline MBG-BRS0203 & Ourense & Maus de Baños, Bande & 48 & $0 \cdot 481$ \\
\hline MBG-BRS0206 & Ourense & Bembibre, Viana do Bolo & 48 & $0 \cdot 487$ \\
\hline MBG-BRS0215 & Ourense & Cameija, Boborás & 47 & $0 \cdot 446$ \\
\hline MBG-BRS0216 & Ourense & Maside & 45 & $0 \cdot 511$ \\
\hline MBG-BRS0220 & Ourense & Amoeiro & 47 & $0 \cdot 493$ \\
\hline MBG-BRS0222 & Ourense & Vilar de San Ginés, A Peroxa & 52 & $0 \cdot 427$ \\
\hline MBG-BRS0224 & Ourense & Conchouso, A Peroxa & 53 & $0 \cdot 530$ \\
\hline MBG-BRS0228 & Ourense & Ordelles, Pereiro de Aguiar & 45 & $0 \cdot 455$ \\
\hline MBG-BRS0232 & Ourense & Tarreirigo, Esgos & 46 & $0 \cdot 476$ \\
\hline MBG-BRS0233 & Ourense & Challoso, Maceda & 49 & $0 \cdot 495$ \\
\hline MBG-BRS0234 & Ourense & Challoso, Maceda & 48 & $0 \cdot 445$ \\
\hline MBG-BRS0235 & Ourense & Challoso, Maceda & 49 & $0 \cdot 518$ \\
\hline MBG-BRS0236 & Ourense & Challoso, Maceda & 45 & $0 \cdot 472$ \\
\hline MBG-BRS0237 & Ourense & Sanguiñedo, Baños de Molgas & 46 & $0 \cdot 492$ \\
\hline MBG-BRS0242 & Ourense & Vilar de Flores, Allariz & 52 & $0 \cdot 518$ \\
\hline MBG-BRS0244 & Ourense & Barrio, Xunqueira de Espadanedo & 52 & $0 \cdot 482$ \\
\hline MBG-BRS0254 & Ourense & A Teixeira & 55 & $0 \cdot 487$ \\
\hline MBG-BRS0256 & Ourense & A Teixeira & 49 & $0 \cdot 420$ \\
\hline
\end{tabular}


Table 1. (Cont.)

\begin{tabular}{|c|c|c|c|c|}
\hline Accession name & $\begin{array}{c}\text { Geographical origin } \\
\text { (Galicia province) }\end{array}$ & Location & $\begin{array}{l}\text { Number of } \\
\text { alleles }\end{array}$ & $\begin{array}{c}\text { Expected } \\
\text { heterozygosity }\end{array}$ \\
\hline MBG-BRS0266 & Ourense & Vozqueimados, Chandrexa de Queixa & 54 & $0 \cdot 485$ \\
\hline MBG-BRS0274 & Ourense & San Juan de Barrio, A Proba de Trives & 53 & $0 \cdot 511$ \\
\hline MBG-BRS0282 & Ourense & Matosiños, La Merca & 51 & $0 \cdot 456$ \\
\hline MBG-BRS0284 & Ourense & Meronzo Grande, La Merca & 56 & $0 \cdot 536$ \\
\hline MBG-BRS0304 & Ourense & Gomariz, Baltar & 50 & $0 \cdot 504$ \\
\hline MBG-BRS0312 & Ourense & Vilar de Barrio & 47 & $0 \cdot 390$ \\
\hline MBG-BRS0322 & Ourense & Flariz, Monterrei & 57 & $0 \cdot 487$ \\
\hline MBG-BRS0401 & A Coruña & San Xiao, Coirós & 43 & $0 \cdot 375$ \\
\hline MBG-BRS0430 & Lugo & Santaballa, Vilalba & 51 & $0 \cdot 472$ \\
\hline MBG-BRS0433 & A Coruña & Santiago & 49 & $0 \cdot 459$ \\
\hline MBG-BRS0440 & Lugo & Llacín, Carballido, A Fonsagrada & 37 & $0 \cdot 302$ \\
\hline MBG-BRS0450 & A Coruña & Lago, Valdoviño & 40 & $0 \cdot 436$ \\
\hline MBG-BRS0451 & A Coruña & O Val, Narón & 51 & $0 \cdot 475$ \\
\hline MBG-BRS0459 & Lugo & Alba, Palas de Rey & 49 & $0 \cdot 443$ \\
\hline MBG-BRS0461 & Lugo & Castro de Rei & 41 & $0 \cdot 338$ \\
\hline MBG-BRS0471 & Lugo & San Julián de Tor, Monforte de Lemos & 44 & $0 \cdot 413$ \\
\hline MBG-BRS0472 & A Coruña & Porta, Sobrado & 48 & $0 \cdot 447$ \\
\hline MBG-BRS0496 & A Coruña & Fosado, Montao, Ordes & 39 & $0 \cdot 421$ \\
\hline MBG-BRS0544 & A Coruña & O Castro, Armentón, Arteixo & 45 & $0 \cdot 433$ \\
\hline MBG-BRS0547 & Lugo & Abadín & 44 & $0 \cdot 450$ \\
\hline MBG-BRS0550 & A Coruña & Trazo & 50 & $0 \cdot 442$ \\
\hline MBG-BRS0552 & Portugal & Lapa-Moimenta & 44 & $0 \cdot 444$ \\
\hline MBG-BRS0553 & Portugal & Pias-Monçao & 49 & $0 \cdot 510$ \\
\hline Mean & & & 48 & $0 \cdot 455$ \\
\hline
\end{tabular}

or secondary stems, and so they are not suitable for obtaining turnip leaves or turnip inflorescences. Commercial varieties grown to obtain turnip inflorescences and turnip leaves have been selected for high production of floral shoots or leaves. However, in the case of many local landraces grown in Galicia, the same landrace can be grown for more than one purpose, allowing the existence of local populations with high levels of variability (Padilla et al. 2005). For example, within some landraces there are plants that have thickened roots and others that produce high numbers of leaves.

These landraces are a valuable resource since they are highly variable, are adapted to the climatic conditions of the area and can be resistant to different pests and diseases. A collection of B. rapa subsp. rapa from north-western Spain is currently kept at 'Misión Biológica de Galicia' (CSIC, Spain). This collection has been characterized based on morphological and agronomical traits (Padilla et al. 2005); some landraces have been found suitable for inclusion in breeding programmes due to their good performance. A better understanding of the genetic diversity present in the collection is necessary in order to optimize its use and maintenance. Previous studies on the genetic diversity present in different $B$. rapa collections have used molecular markers, proving that they are useful tools for the characterization of agricultural crop diversity (Persson et al. 2001; Zhao et al. 2005;
Ofori et al. 2008). The objectives of the present work were to assess the genetic diversity present in the B. rapa subsp. rapa collection maintained at Misión Biológica de Galicia, to establish genetic relationships among populations and to study the genetic structure of the collection using simple sequence repeats (SSRs).

\section{MATERIALS AND METHODS \\ Plant material and DNA analysis}

Eighty populations of $B$. rapa subsp. rapa collected in north-western Spain and the north of Portugal and kept at the Misión Biológica de Galicia (CSIC, Spain) Gene Bank were chosen for evaluation in the present study (Table 1). Populations from north-western Spain were collected throughout the region, in coastal and inland locations (Fig. 1). A previous study (Padilla et al. 2005) classified the 80 populations into different clusters, based on morphological and agronomical traits. Because populations are heterogeneous and highly variable, 20 individuals from each population were analysed. Plants were sown in seedbeds and, 40 days later, the fourth or fifth leaf of each individual were used for DNA extraction following the method of Liu \& Whittier (1994) but without using microbeads. After an initial screening using 40 different SSRs, 18 SSRs that were polymorphic and 


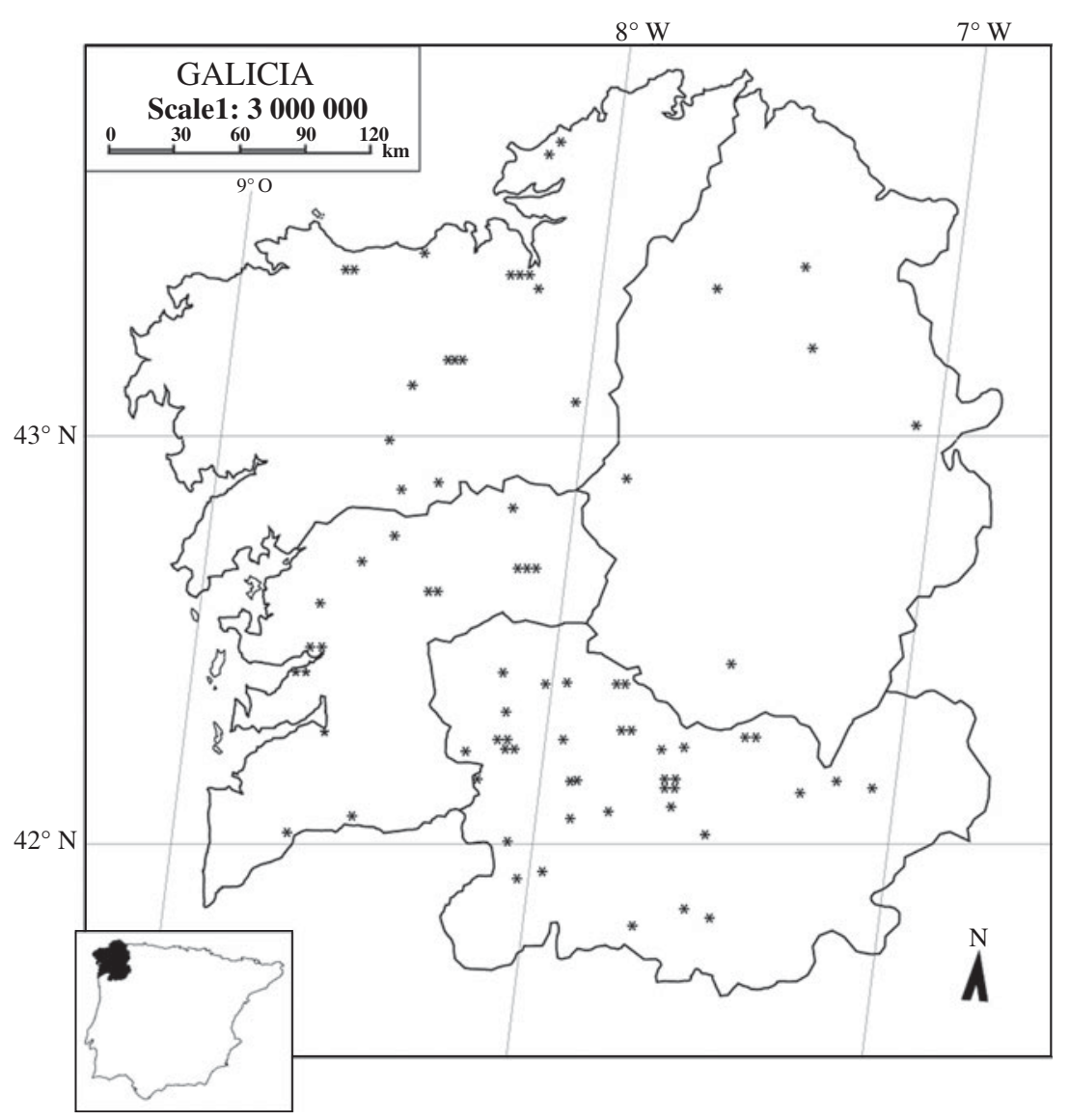

Fig. 1. Distribution of the populations analysed in north-western Spain.

independent were finally chosen to carry out the analysis (Table 2). Amplification of SSRs was performed using a PTC-100 $100^{\mathrm{TM}}$ Thermal Cycler (MJ Research, Watertown, MA, USA). The amplification consisted of a denaturing step at $95^{\circ} \mathrm{C}$ for $5 \mathrm{~min}$ followed by 35 denaturing cycles at $95^{\circ} \mathrm{C}$ for $30 \mathrm{~s}$, annealing at $56^{\circ} \mathrm{C}$ for $30 \mathrm{~s}$ and elongation at $72^{\circ} \mathrm{C}$ for $30 \mathrm{~s}$. The programme ended with an extra elongation period of $10 \mathrm{~min}$ followed by a continuous cycle at $4{ }^{\circ} \mathrm{C}$. Reactions were carried out with $50 \mathrm{ng}$ of each primer, 0.6 unit of Taq polymerase (BioTaq, Kapa Biosystems), $200 \mu \mathrm{M}$ each dNTP, $1 \times$ reaction buffer, $2.0 \mathrm{~mm} \mathrm{MgCl}_{2}, 50 \mathrm{ng}$ DNA template, in a final volume of $25 \mu \mathrm{l}$ made up with distilled and autoclaved water. After amplification, SSR products were separated by electrophoresis on $0.6 \mathrm{~g} / \mathrm{ml}$ non-denaturing acrylamide gels run in $1 \times \mathrm{TBE}$ buffer. Gels were stained with Ethidium bromide, run for $c .2 \mathrm{~h}$ at $250 \mathrm{~V}$ and then visualized under UV light. Bands amplified by each SSR were sized by comparison with hyperladder IV (Bioline). Alleles were scored as present (1) or absent ( 0 ) for each SSR across populations. A band was considered as present in a population if it was amplified in one individual of the 20 studied from the population.

\section{Genetic diversity and genetic relationships}

The number of alleles was computed for each SSR and each population. Average polymorphic information content was computed for each locus and expected heterozygosity average was computed for each population. A similarity matrix with presence-absence data was constructed using the NTSYS-PC version 2.1 (Rohlf 1998) based on the Dice coefficient, also known as the similarity coefficient of Nei \& $\mathrm{Li}$ (1979). The Dice coefficient is computed as $2 a$ / $(2 a+b+c)$, where $a$ is the number of SSR bands shared by genotypes in each pairwise comparison and $b$ and $c$ are the number of SSR bands present in one genotype and not present in the other. Cluster analysis was performed using the unweighted pair group method with arithmetic averages (UPGMA) with the program NTSYS (Rohlf 1998). A cophenetic 
Table 2. List of SSRs employed in this study, number of alleles and polymorphic information content

\begin{tabular}{lcc}
\hline \hline Primer pair* & $\begin{array}{c}\text { Number of } \\
\text { alleles }\end{array}$ & $\begin{array}{c}\text { Polymorphic } \\
\text { information } \\
\text { content }\end{array}$ \\
\hline BRMS-034 & 4 & $0 \cdot 43$ \\
BRMS-043 & 3 & $0 \cdot 56$ \\
BRMS-027 & 6 & $0 \cdot 74$ \\
BRMS-007 & 9 & $0 \cdot 78$ \\
BRMS-040 & 6 & $0 \cdot 57$ \\
BRMS-051 & 3 & $0 \cdot 31$ \\
BRMS-056 & 5 & $0 \cdot 73$ \\
BRMS-006 & 8 & $0 \cdot 80$ \\
BRMS-005 & 6 & $0 \cdot 61$ \\
SSR Ra2-G09 & 5 & $0 \cdot 68$ \\
SSR Ni2-F11 & 3 & $0 \cdot 59$ \\
SSR O111-H06 & 3 & $0 \cdot 42$ \\
FITO 008 & 4 & $0 \cdot 65$ \\
FITO 035 & 3 & $0 \cdot 50$ \\
FITO 036 & 3 & $0 \cdot 33$ \\
FITO 043 & 4 & $0 \cdot 52$ \\
FITO 057 & 4 & $0 \cdot 28$ \\
FITO 063 & 3 & $0 \cdot 57$ \\
Mean & $4 \cdot 5$ & $0 \cdot 56$ \\
\hline \hline
\end{tabular}

* Primer sequences and annealing temperatures of primer pair starting with 'BRMS', 'SSR' and 'FITO' were obtained from Lowe et al. (2004), Suwabe et al. (2002) and IniguezLuy et al. (2008), respectively.

correlation was calculated to test for the goodness-offit between the similarity matrix obtained from the cluster and the original similarity matrix. Bootstrap values to ascertain the internal support of clusters were calculated with the software Win Boot (Yap \& Nelson 1996).

\section{Genetic structure}

An analysis of molecular variance (AMOVA; Excoffier et al. 1992) based on the dissimilarity matrix of pairwise individuals was performed using Arlequin version 3.2 (Excoffier et al. 2005) to assess the genetic structure of the B. rapa germplasm. This analysis partitioned the total SSR variation into within- and among-population variation components. The significance level for variance components was tested probabilistically by a permutation test. The overall Fst was computed with Arlequin version 3.2 and gene flow was estimated from Fst according to Nei (1973) as follows:

$$
N m=0 \cdot 25(1-F s t) / F s t
$$

Based on the genotype of the marker loci, individuals were assigned probabilistically into a given number of clusters inferred by the Bayesian approach of STRUCTURE (Pritchard et al. 2000). The number of clusters $(k)$ chosen for modelling the data varied from 1 to 80 . The likelihood of each $k$ value $L(k)$ was computed based on an initial burn-in period of 10000 interactions, followed by 10000 Monte Carlo interactions. The range of $k$ values that showed the highest likelihoods (from $k=1$ to $k=43$ ) were run five different times. All runs used an admixture model with correlated allele frequencies and the parameter of individual admixture (alpha) was set to be the same for all the clusters. The accepted number of clusters $(k)$ was identified using the procedure described by Evanno et al. (2005). Evanno et al. (2005), using simulated data, found that the distribution of $L(k)$ did not show a clear mode for the true $k$ value. They proposed an ad hoc quantity based on the second-order change of the likelihood with respect to $k(\Delta k)$. The parameter $\Delta k=\mathrm{m}$ $\left(\left|L^{\prime \prime}\right|\right) / s[L(k)]$ is calculated as the mean of absolute values of the second-order change of the likelihood distribution divided by the standard deviation of likelihood. The modal value of this distribution is interpreted as the true number of clusters $k$ (Evanno et al. 2005).

\section{RESULTS}

\section{Genetic diversity and genetic relationships}

The 18 SSRs detected a total of 83 different alleles across populations (Table 2). The number of alleles per locus ranged from 3 (several SSRs) to 9 (with BRMS 007), with a mean value of $4 \cdot 5$. The polymorphic information content ranged from $0 \cdot 28$ (using FITO 057) to $0 \cdot 80$ (using BRMS-006) (Table 2).

The genetic variation of each population was quantified by the number of alleles per locus and average heterozygosity (Table 1). The number of alleles per population ranged from 33 (MBGBRS0123) to 57 (MBG-BRS0057), with a mean value of 48 , and the expected heterozygosity ranged between 0.265 (MBG-BRS0123) and 0.536 (MBGBRS0284) with a mean value of $0 \cdot 455$. The higher number of alleles and expected heterozygosity indicates the presence of a larger genetic variation; four populations: MBG-BRS0123, MBG-BRS0099, MBG-BRS0440 and MBG-BRS0461, showed the lowest level of genetic diversity and two populations, MBG-BRS0284 and MBG-BRS0139, showed the highest level of genetic diversity.

To clarify the relationships among populations a dendrogram based on the Dice coefficient, using the UPGMA method, was constructed (data not shown). Most of the populations were classified together for a distance of $0 \cdot 82$. Bootstrap analysis was used to evaluate the degree of support for clusters within the dendrogram (data not shown). Major clusters and subgroups within clusters are supported by low bootstrap values. The highest bootstrap values $(>0 \cdot 30)$ corresponded to clusters between pairs of populations; the remaining clusters showed support $\leqslant 0 \cdot 30$. The 
Table 3. AMOVA for 80 populations of $\mathrm{B}$. rapa

\begin{tabular}{lrcccc}
\hline \hline Source of variation & D.F. & $\begin{array}{c}\text { Sum of } \\
\text { squares }\end{array}$ & $\begin{array}{c}\text { Variance } \\
\text { components }\end{array}$ & $\begin{array}{c}\text { Proportion of } \\
\text { variation }\end{array}$ & $P$ value* \\
\hline Among populations & 79 & 1099 & 0.480 & $0 \cdot 10$ & $<0 \cdot 001$ \\
Within populations & 1519 & 6560 & 4.318 & 0.90 & \\
Total & 1598 & 7659 & 4.798 & & \\
\hline \hline
\end{tabular}

* Probability to obtain a random value greater than and equal to an observed value tested by 1023 permutations.

cophenetic correlation between the similarity matrix based on Dice coefficient and the similarity matrix obtained by the cluster was $0 \cdot 80$.

\section{Genetic structure}

Most of the variation was located at the withinpopulation level (0.90). The source of variation among populations accounted for 0.10 of the variability (Table 3$)$. The fixation index (Fst) for the populations analysed was $0 \cdot 100$ and the level of gene flow based on Fst was 2.25 migrants per generation.

To detect the population structure of the total sample, the Bayesian approach implemented in STRUCTURE (http://pritch.bsd.uchicago.edu/structure. $\mathrm{html}$, verified 13 Jan 2010) was used. This program allows assignment of individuals to $k$ clusters and determines the proportion of genome of each individual in each assigned cluster. The most probable $k$ value, taking into account $L(k)$ was 28 (Fig. 2). However, when $\Delta k$ was computed, the most probable number of clusters supported by the 1600 individuals analysed was 1 (Fig. 2).

\section{DISCUSSION}

\section{Genetic diversity and genetic relationships}

The diversity found within B. rapa populations analysed in the present study was higher than in the work reported by Fu \& Gugel (2009), who detected levels of heterozygosity from $0 \cdot 120$ to 0.197 in 10 cultivars of B. rapa subsp. oleifera analysed by SSR markers. The lower level of diversity found by $\mathrm{Fu} \&$ Gugel (2009) can be explained because the populations analysed were related by origin. The heterozygosity found by Ofori et al. (2008) in three openpollinated cultivars of B. rapa subsp. oleifera (ranging from 0.480 to 0.530 ) was similar to those found in some of the populations analysed in the present work.

There was a broad range of genetic diversity in the populations analysed. Populations also showed a high level of genetic diversity for morphological and agronomical traits in previous work (Padilla et al. 2005). Therefore, populations kept at the Gene Bank at Misión Biológica de Galicia offer good potential for further genetic improvement due to their high variability. Traditional varieties grown for years in
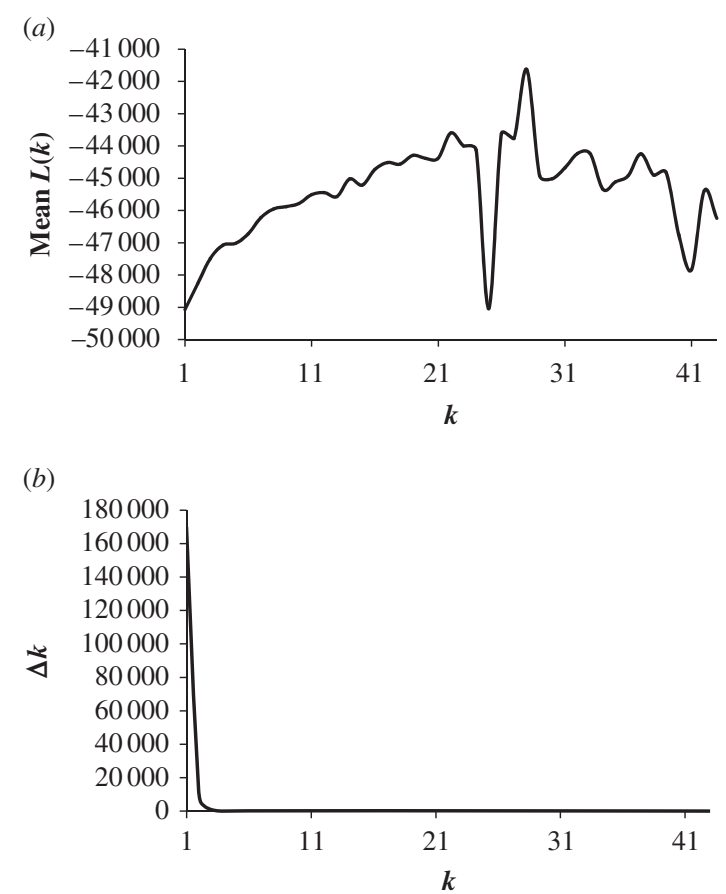

Fig. 2. (a) Distribution of $L(k)$ for $k=1$ to $k=43$ based on an initial burn-in period of 10000 interactions, followed by 10000 Monte Carlo interactions and $(b)$ distribution of $\Delta k$ for $k=1$ to $k=43$ computed using the procedure described by Evanno et al. (2005).

north-western Spain have been selected both naturally and artificially for yield, resistance to pest and diseases and adaptation to the area where they are grown. They could be an important source of useful diversity for agronomic characteristics and resistance to diseases and pests for Brassica breeding programmes.

To study relationships among populations, a cluster analysis was carried out. Populations did not differ significantly since the majority of the populations were classified together. Clusters of populations were supported by low bootstrap values and the cophenetic correlation was moderate. An analysis of the genetic structure of the collection was carried out to study in detail the causes of this low level of differentiation. 


\section{Genetic structure}

Most of the variability found in the populations analysed was due to the source of variation within populations. Previous studies on diversity within- and among-cultivar groups have been reported in B. rapa. Persson et al. (2001), using allozymes, reported 0.81 within-cultivar genetic diversity in turnip $B$. rapa from Northern Europe. High levels of within-population variation $(0.90$ and 0.83$)$ were found in cultivars of B. rapa subsp. oleifera (Ofori et al. 2008; Fu \& Gugel 2009). Zhao et al. (2005), applying AFLP markers, reported comparable genetic diversity among and within different cultivars belonging to different B. rapa crops, including leafy vegetables, oilseed, root vegetables and fodder collected world-wide.

The results presented here confirm the low differentiation among populations, which is not surprising for an open-pollinated species as B. rapa. The high genetic diversity within populations is required to avoid inbreeding and to enable a high yield since, as an obligate outcrossing crop, B. rapa shows a severe inbreeding depression. Examples of similar patterns can also be found in other open-pollinated crops such as maize (Reif et al. 2003) and sugar beet (Novakova et al. 2008).

Fst is a measure of the extent of genetic differentiation among subpopulations and can range from 0 (no differentiation) to 1 (complete differentiation). As expected for an outcrossing crop, a low overall differentiation among populations was observed. Gene flow is the movement of genes within and between populations. Generally, a single migrant per generation among idealized populations would be sufficient to prevent complete differentiation (Wright 1969). In the present study, the level of gene flow based on $F s t$ was $2 \cdot 25$ migrants per generation, which confirms the supposition of little genetic differentiation among populations. Gene flow in the collection of B. rapa subsp. rapa would occur naturally by means of migration (movement of pollen or seed carriers) or artificially by means of interchange or mixture of seed by growers.

The most probable $k$ value computed with the method proposed by Evanno et al. (2005) does not agree with the one obtained by taking into account the distribution of $L(k)$. Evanno et al. (2005) have demonstrated that $L(k)$ does not show a clear mode for the true $k$ value; however, the parameter $\Delta k$, taking into account changes of the likelihood distribution and the standard deviation of likelihood, is more reliable. In this case, although $L(k)$ of $k=1$ was low, its standard error was very small, then its $\Delta k$ was by far the highest value of the distribution, and therefore it can be concluded that all populations belong to the same cluster.

Using these data on SSRs, the 80 populations were clustered together independently of their geographical origin or morphological resemblance. This last result contrasts with Padilla et al. (2005), who classified all the accessions of the same B. rapa subsp. rapa collection into five clusters, based on morphological and agronomical traits, related to the potential use of the crop: vigorous plants for turnip leaf production, plants with a high number of secondary stems for turnip inflorescences and plants with the root thickened for turnip production. The lack of agreement between the classifications could be partly due to the fact that differences in the use of the plant are determined by few genes and that the number of SSR markers used in the present work is not enough to detect their effect.

After studying the B. rapa subsp. rapa kept at Misión Biológica de Galicia collection it can be concluded that it has a broad range of genetic diversity. Most of the variability was found within populations, due to: high rates of allogamy in the species, migration, interchange of seed or mixing of seed by growers. This means that populations are not differentiated, and therefore they can be considered as samples from a highly variable metapopulation that can be used for B. rapa breeding programmes.

As a result of the present work, the new knowledge on the genetic diversity and genetic structure of this collection will be useful for its utilization and management.

The authors thank the invaluable work carried out by Rosaura Abilleira, Eva Fernández, Susana Calvo and Elena Zubiaurre. Marta Francisco and Margarita Lema acknowledge their grants from the I3P program (CSIC, Spain). This research was supported by project RF-2006-00028-00-00 and the Excma. Diputación Provincial de Pontevedra, Spain.

\section{REFERENCES}

Evanno, G., Regnaut, S. \& Goudet, J. (2005). Detecting the number of clusters of individuals using the software STRUCTURE: a simulation study. Molecular Ecology 14, 2611-2620.

Excoffier, L., Smouse, P. E. \& Quattro, J. M. (1992). Analysis of molecular variance inferred from metric distances among DNA haplotypes: application to human mitochondrial DNA restriction data. Genetics 131, 479-491.
Excoffier, L., Laval, G. \& Schneider, S. (2005). Arlequin (version 3.0): an integrated software package for population genetics data analysis. Evolutionary Bioinformatics Online 1, 47-50.

Fu, Y.-B. \& Gugel, R. K. (2009). Genetic variability of Canadian elite cultivars of summer turnip rape (Brassica rapa L.) revealed by simple sequence repeat markers. Canadian Journal of Plant Science 89, 865-874. 
Gómez-Campo, C. \& Prakash, S. (1999). Origin and domestication. In Biology of Brassica Coenospecies (Ed. C. Gómez-Campo), pp. 33-58. Amsterdam, The Netherlands: Elsevier.

Iniguez-Luy, F. L., Voort, A. V. \& Osborn, T. C. (2008). Development of a set of public SSR markers derived from genomic sequence of a rapid cycling Brassica oleracea L. genotype. Theoretical and Applied Genetics 117, 977985.

Liu, Y. G. \& Whittier, R. F. (1994). Rapid preparation of megabase plant DNA from nuclei in agarose plugs and microbeads. Nucleic Acids Research 22, 2168-2169.

Lowe, A. J., Moule, C., Trick, M. \& Edwards, K. J. (2004). Efficient large-scale development of microsatellites for marker and mapping applications in Brassica crop species. Theoretical and Applied Genetics 108, 1103-1112.

NeI, M. (1973). Analysis of gene diversity in subdivided populations. Proceedings of the National Academy of Science of the United States of America 70, 3321-3323.

NeI, M. \& LI, W. H. (1979). Mathematical model for studying genetic variation in terms of restriction endonucleases. Proceedings of the National Academy of Science of the United States of America 76, 5269-5273.

Novakova, K., Hamouz, P., Holec, J. \& Soukup, J. (2008). Genetic diversity of Beta-complex assessed by RAPD markers. Journal of Plant Diseases and Protection 21 (Special Issue), 437-440.

Ofori, A., Becker, H. C. \& Kopisch-Obuch, F. J. (2008). Effect of crop improvement on genetic diversity in oilseed Brassica rapa (turnip-rape) cultivars, detected by SSR markers. Journal of Applied Genetics 49, 207-212.

Padilla, G., Cartea, M. E., Rodríquez, V. M. \& Ordás, A. (2005). Genetic diversity in a germplasm collection of
Brassica rapa subsp rapa L. from northwestern Spain. Euphytica 145, 171-180.

Persson, K., Fält, A.-S. \& Von Bothmer, R. (2001). Genetic diversity of allozymes in turnip (Brassica rapa L. var rapa) from the Nordic area. Hereditas 134, 43-52.

Pritchard, J. K., Stephens, M. \& Donnelly, P. (2000). Inference of population structure using multilocus genotype data. Genetics 155, 945-959.

Reif, J. C., Melchinger, A. E., XIA, X. C., Warburton, M. L., Hoisington, D. A., Vasal, S. K., Srinivasan, G., Bohn, M. \& Frisch, M. (2003). Genetic distance based on simple sequence repeats and heterosis in tropical maize populations. Crop Science 43, 1275-1282.

RohlF, F. J. (1998). NTSYS-pc. Numerical Taxonomy and Multivariate Analysis System. Version 2.1. New York: EXETER software.

Suwabe, K., Inetani, H., Nunome, T., Kage, T. \& Hirai, M. (2002). Isolation and characterization of microsatellites in Brassica rapa L. Theoretical and Applied Genetics 104, 1092-1098.

Wright, S. (1969). Evolution and the Genetics of Populations, 2: The Theory of Gene Frequencies. Chicago, IL: University of Chicago Press.

Yap, I. V. \& Nelson, R. J. (1996). Winboot: a Program for Performing Bootstrap Analysis of Binary Data to Determine the Confidence Limits of UPGMA-based Dendograms. Discussion Paper Series No. 14. Manila, The Philippines: IRRI.

Zhao, J., Wang, X., Deng, B., Lou, P., Wu, J., Sun, R., Xu, Z., Vromans, J., Koornneef, M. \& Bonnema, G. (2005). Genetic relationships within Brassica rapa as inferred from AFLP fingerprints. Theoretical and Applied Genetics 110, 1301-1314. 